\title{
REDIMAT
}

Instructions for authors, subscriptions and further details:

http://redimat.hipatiapress.com

\section{Modeling Metacognition: Making Thinking Visible in a Content Course for Teachers}

Kansas Conrady ${ }^{1}$

1) University of Oklahoma, United States of America.

Date of publication: June $24^{\text {th }}, 2015$

Edition period: June 2015-October 2015

To cite this article: Conrady, K. (2015). Modeling metacognition: Making thinking visible in a content course for teachers. REDIMAT, Vol 4(2), 132- 160. doi: 10.17583/redimat.2015.1422

To link this article: http://dx.doi.org/10.17583/redimat.2015.1422

\section{PLEASE SCROLL DOWN FOR ARTICLE}

The terms and conditions of use are related to the Open Journal System and to Creative Commons Attribution License (CC-BY). 


\title{
Modeling Metacognition: Making Thinking Visible in a Content Course for Teachers
}

\author{
Kansas Conrady \\ University of Oklahoma
}

(Received: 15 February 2015; Accepted: 11 June 2015; Published: 24 June 2015)

\section{Abstract}

Helping students develop their ability to use the mathematical practices relies on their awareness of and ability to share their thinking to be used as part of classroom instruction. This type of instruction tends to be different from most teachers mathematics learning experiences thus requiring teachers to rethink what it means to teach mathematics without a model for reference. This pre-service geometry content course was designed specifically for future elementary teachers with the intent of modeling effective non-traditional methods of instruction. Unfortunately, analysis of classroom observations suggested that even in this carefully designed inquiry-based course, there is a lack of cognitive and metacognitive thoughts being made visible for use as part of instruction. Content courses, such as this one, are the final opportunities to help students learn mathematics content in an environment supported by positive research findings, thus teacher education is missing an opportunity to provide a potentially powerful learning experience for future teachers.

Keywords: Teacher education, content courses, mathematics, elementary teachers 


\section{Modelando la Metacognición: Haciendo Visible el Pensamiento en un Curso Orientado a Profesorado}

Kansas Conrady

University of Oklahoma

(Recibido: 15 February 2015; Aceptado: 11 June 2015; Publicado: 24 June 2015)

\section{Abstract}

Ayudar a estudiantes a desarrollar su habilidad en el uso de las prácticas matemáticas se basa en su confianza y habilidad para compartir su pensamiento como parte de la formación dentro del aula. Este tipo de formación tiende a ser diferente de la may oría de prácticas que los maestros de matemáticas han aprendido, de manera que requiere que los maestros repiensen qué quiere decir enseñar matemáticas sin un modelo de referencia. Este curso de geometría para profesorado en formación fue diseñado específicamente para futuros maestros de educación primaria, con la intención de modelar de manera efectiva métodos no tradicionales de instrucción. Desafortunadamente, el análisis de las observaciones de aula sugiere que incluso en este curso diseñado cuidadosamente, existe un vacío de razonamiento cognitivo y metacognitivo que se haga visible para su uso en la formación. Los cursos de contenidos, como éste, son la última oportunidad para ayudar a los estudiantes a aprender matemáticas en un contexto apoy ado por las contribuciones de la investigación, por tanto la educación de profesorado se está perdiendo una oportunidad de proveer un aprendizaje potencialmente positivo para la experiencia de los futuros maestros.

Keywords: Formación de profesorado, cursos de contenidos, matemáticas, magisterio 


\section{Conrady - Modeling Metacognition}

W ith the adoption of the Eight Mathematical Practices, teachers around the country are seeking ways to understand and change their instruction to be in line with these standards. Supporting the development of students' Mathematical Practices requires a deep understanding of not only mathematics content, but also a variety of underlying thinking processes that can and should be used as a part of effective mathematics instruction. Unfortunately, the behind the scenes and often times messy thinking processes used to do mathematics are rarely shared and even more rarely does this thinking become the object of classroom discussions. While many believe that conversations about mathematics teaching have moved far beyond metacognition, revisiting ideas of metacognition as an analytic lens for the type of instruction being modeled in mathematics content coursew ork provides insight for the final content learning experiences provided for pre-service elementary teachers.

\section{What is Metacognition?}

Metacognition is most commonly described as thinking about thinking, but more formally as self-monitoring and control of thought (Flavell, 1979; Goos, Galbraith, \& Renshaw, 2002; Martinez, 2006; Schraw \& Dennison, 1994). It is the awareness and regulation of one's cognitive processes in order to achieve a specific goal (Goos, Galbraith, \& Renshaw, 2002). Flavell (1979) clarifies the differences between cognitive and metacognitive thought by explaining, "Cognitive strategies are invoked to make cognitive processes, metacognitive strategies to monitor it" (p. 909).

Metacognitive thoughts can be separated into two categories, knowledge of cognition and regulation of cognition (Schraw \& Dennison, 1994). Knowledge of cognition includes declarative, procedural, and conditional know ledge. This could also be considered know ledge about what you know (declarative knowledge), knowledge about how to do a procedure (procedural knowledge), and knowledge about when and why to do a particular procedure (conditional knowledge). Regulation of cognition refers to the monitoring of the thought process and includes planning, managing information, monitoring progress, debugging when things go wrong, and evaluating one's over effectiveness and efficiency of one's thinking (see Figure 1). More generally stated, making a plan, identifying the necessary information involved with that plan, monitoring progress, 
making decisions about the plan and collecting information when things go wrong or once the end of the problem has been reached.

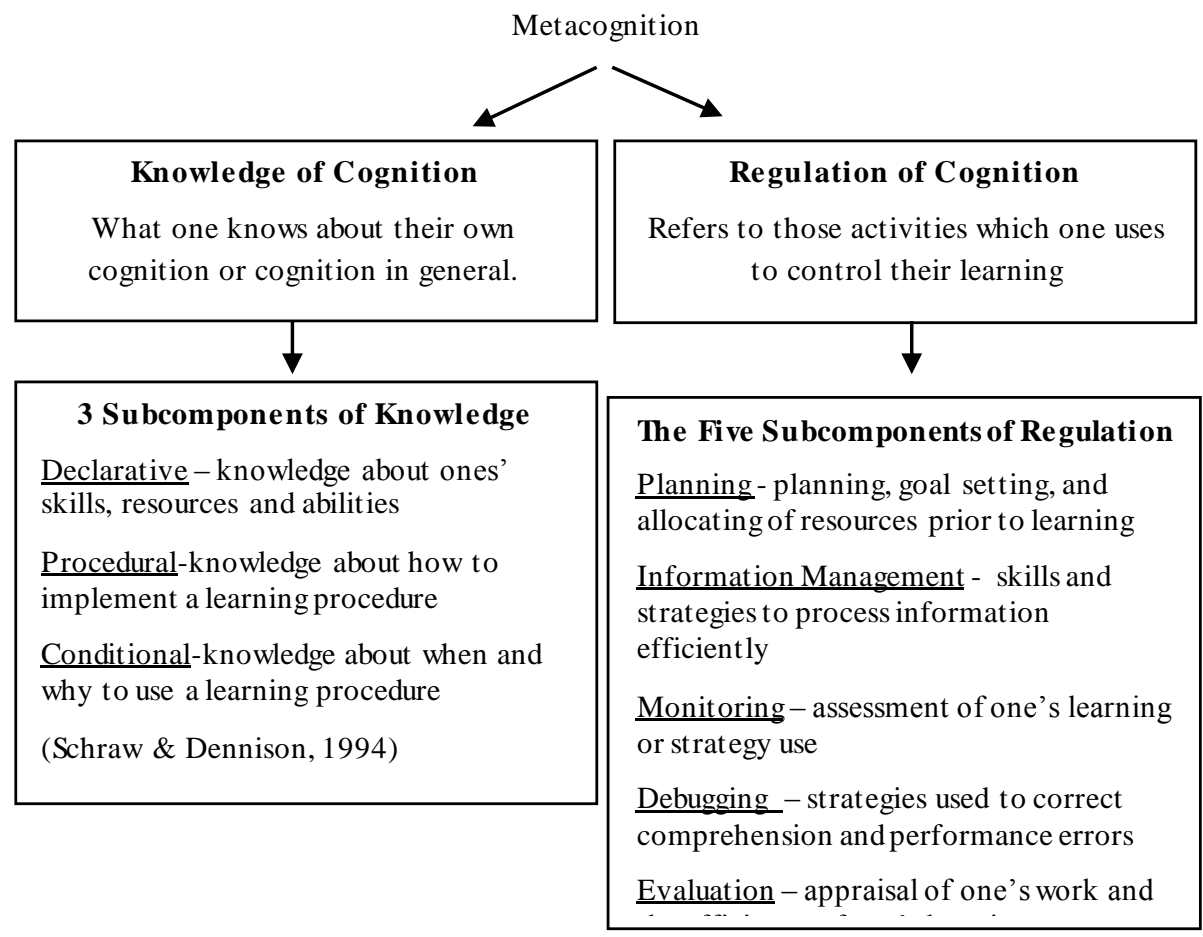

Figure 1. Taxonomy of Metacognitive Thoughts (Schraw \& Dennis on, 1994)

\section{Why Emphasize Metacognition?}

The knowledge and regulation of one's thinking allows for more effective use of what one knows (Schoenfeld, 2007). Further, metacognition works in conjunction with student's general mathematics knowledge base, strategy knowledge, and their own disposition and beliefs about themselves and mathematics to determine a student's overall mathematical proficiency (Schoenfeld, 2007; NRC, 2001). Both the positive correlation between metacognition and success in mathematics and the ability to help students improve their metacognitive thinking are well documented (Garofalo, 1987; Lester, 1989; Schoenfeld, 2007; Schoenfeld, 1992). Metacognitive thinking 


\section{Conrady - Modeling Metacognition}

needs to be explicitly taught and is especially beneficial for weaker students (Bransford, Brown, \& Cocking, 2000; Lin, 2001). The knowledge of students' own thinking allows for greater efficiency, flexibility, and transferability of their knowledge to new situations which develops a greater ability to adapt to diverse tasks and ultimately lead to better learning (Pintrich, 2002; Sarver, 2006). However, students do not obtain this knowledge automatically. Students must instead develop their metacognitive knowledge through direct and explicit instruction in which the teacher helps the student access their own thinking (Pintrich, 2002; Sarver, 2006).

\section{Developing Metacognitive Thinking}

The sharing of thoughts and using those thoughts as objects for thinking is at the heart of promoting metacognitive development. Vygotsky's (1986) sociocultural theory provides a theoretical base for researchers to collect and analyze data about metacognition. Researchers that have employed this perspective have suggested that higher-order thought is cultivated in a social setting because students hear and see the mathematical approaches of their peers, compare their own strategies with new ideas and determine which methods are most accurate and efficient (Pintrich, 2002). Researchers also suggest that it is through the sociocultural setting that students are able to interact and participate in the higher-quality thinking that promotes metacognitive thinking which then leads to greater success in mathematics (Goos, et al., 2002; Martinez, 2006; Pintrich, 2002; Pugalee, 2001; Sarver, 2006).

The explicit modeling of one student's metacognition helps other students develop their own metacognitive thinking. Hearing and/or seeing the thinking of another student, then comparing it with one's own thoughts, evaluating the shared thinking, and determining what to do with the thought is critical for metacognitive development. Metacognition is commonly divided into two separate, but related components. The first component is knowledge of cognition and encompasses declarative, procedural, and conditional knowledge. Declarative knowledge is knowledge about one's skills, resources, and abilities. Procedural knowledge is knowledge about how to implement a learning procedure. Conditional knowledge is knowledge about when and why to use a particular learning procedure. 
Knowledge of cognition, in contrast to regulation, is simply what one know s about their own thinking or thinking in general. What one does with that information is the second category, regulation of cognition. This category encompasses the activities used to control one's thinking such as planning, information management, monitoring, debugging, and evaluation. Planning consists of goal setting and resource allocation while information management refers to skills and strategies used to process information efficiently. Monitoring is an on-going assessment of one's learning or strategy use. Debugging strategies are used to correct comprehension and performance errors and lastly, evaluation is an appraisal of the accuracy and efficiency of one's learning.

\section{Role of the Teacher in Developing Metacognitive Thinking}

Schraw's (1994) framework emphasizes the importance of the overall environment and requires that students share and compare their thinking processes with others. Designing and managing this type of environment is ultimately the responsibility of the teacher. The teacher must realize that direct instruction of a standard algorithm is not satisfactory for promoting metacognitive development and thus must also provide opportunities for students to learn why and when to use the particular procedure. This is accomplished through carefully designed activities such as whole class discussions, modeling of the problem solving process, think aloud, interviews, portfolio assessments, questioning, writing about thinking, prompting, using sentence starters to get the thinking process started, identification and evaluation of errors, or explicit instruction about thinking and metacognition (Flavell, 1979; Goos, et al., 2002; Pintrich, 2002; Sarver, 2006). Teachers must also realize their important and difficult role of managing conversations and ensuring the inclusion of metacognitive thinking. Metacognitive abilities must be explicitly developed in students thus it is important that teachers organize activities to help students learn how to learn (Lin, 2001). Teachers must "model and coach, probe and challenge, guide and monitor, motivate and encourage, expect and hold accountable, and asses and prompt" so that students will "grow intellectually, socially, and personally." (Crawford, 2007, p. 131)

While the teacher's role has been recognized as important in the development of metacognitive thought, and while this type of thought has 


\section{Conrady - Modeling Metacognition}

been deemed important and worthy of research efforts, there remains a lack of understanding of how to support teachers in developing student's metacognitive processes (Lin, 2001) and the Eight Mathematical Practices. This is especially true in terms of teacher educ ation and the content learning experiences pre-service teachers receive as part of their undergraduate education. Because of pre-service teacher's tendency to teach how they were taught, it is important that they have opportunities to learn and make sense of mathematics in an environment that promotes the development of metacognitive thinking and embraces the Practices. This type of environment would allow pre-service teachers to share, compare, and analyze, and internalize a variety of thought processes which would lead to a greater understanding of the mathematics they were teaching as well as the development of an image of an environment to replicate in their own future classrooms.

The purpose of this study is to describe the explicit modeling of metacognitive thought embedded in a purposefully selected geometry content course for PSETs. More specifically, the study was guided by asking what type of metacognitive thoughts is shared during classroom opportunities for learning mathematics?

\section{Methods}

Data for this naturalistic inquiry study was collected from a sophomore level geometry content course for students pursuing a degree in education at a mid-size regional university in a suburban setting. This course was selected based on the instructor's commitment to providing instructional experiences aligned with the course textbook. Further, the mathematics department fully supports the course instructor as she implements nontraditional methods of instruction by providing the appropriate instructional space, materials such as class sets of manipulatives, and encouragement to students when they are unsure of the less familiar learning environment. Further, this course is commonly identified by other math faculty, previous course instructors, and former students as different and unique because students are required to talk with each other and explore mathematical ideas to develop a conceptual understanding rather than just listening to the instructor tell them how to follow a procedure. 
The instructor has an extensive history teaching the course and taught multiple sections during the semester of data collection. The two sections were selected for this study based on the researchers availability to be present for several of the class sessions. Student enrollment in the MWF morning section consisted of 28 students, 23 of which consented to participate in the study. Enrollment in the TR evening section consisted of 29 students, 28 of which consented to participate in the study. Based on participant responses on demographic data, participants were mostly white $(n=15,19)$, mostly female $(n=14,24)$, and mostly elementary education majors $(n=9,16)$.

\section{Data and Analysis}

Fourteen classroom observations were conducted as a part of a larger study that also included self-reported data from both instructor interviews and student surveys. As a non-participant observer (Merriam, 1998), the researcher observed eight sessions during the MWF section and six class sessions during the TR section. The observations were conducted in every class meeting between Exam 2 and Exam 3 with the exception of two MWF meetings. The observations were prearranged with the instructor, all were videotaped, and field notes were taken during the observation (Emerson, Fretz, \& Shaw, 1995). Because all class sessions followed similar patterns and class norms were well established, three MWF meetings and the corresponding TR activities were selected at random to be transcribed. Saturation of data was reached through the use of this subset of classroom observations and provided a representation of enacted instructional practices and instructional language that supported metacognitive development.

A subset of videos was selected for transcription due to limited resources and well-established class norms near the end of the sixteen-week semester. Classroom observation videos were transcribed with an emphasis on classroom dialogue. Tone and gestures were also included in the transcript when they offered depth and meaning to the overall data. The transcripts were organized by textbook page references so that the MWF Friday discussions of a page were paired with the TR discussions of the same page. The observation transcripts then underwent two separate analyses. While both were content analyses, the first was an inductive 


\section{Conrady - Modeling Metacognition}

analysis which involved discovering patterns from the data in light of the lenses previously described (Patton, 2002). For this analysis, the researcher read through all data making notes about what was occurring in the classroom. These notes were then organized into themes. A final pass was made through the data to confirm the consistency of the coding. This analysis provided insight into the overall classroom environment.

The second method of content analysis used for the classroom observations was a deductive analysis where the data was analyzed using Schraw and Denison's (1994) framew ork defining metacognition and its sub-components -Patton, 2002- (see Figure 1 for a model of this framew ork). To complete this analysis, the researcher made a first pass through the data to identify all explicit episodes of metacognitive thinking. A metacognitive episode typically began with a question posed by a student on the homework assignment and consisted of multiple interactions between the student and instructor. The episode typically ended when the conversation moved on to a new topic.

After identifying episodes of shared metacognition, several passes were made through the observation transcripts such that each shared episode was coded for the appropriate subcomponent of metacognition as described by Schraw and Dennison (1994). Each pass through the data focused on a single subcomponent and each subsequent pass was used to code for the next subcomponent while also verifying previous codes. A final pass through the data was made to verify all codes and create a tally for each subcomponent (see Appendix A for coding samples). Episodes could have been coded in both a knowledge subcomponent and a regulation subcomponent since knowledge is a process of knowing what you know while regulation is doing something with that knowledge. In addition to coding for the subcomponent, each episode was also coded for who provided the thought. An episode was coded as student if the student provided the thought, teacher if the teacher provided the thought, or both student and teacher if the episode relied on both the student's and instructor's interaction. This process of coding for both type and supplier of the thought allowed the researcher to describe who was thinking and what type of thinking was being shared in the classroom. 


\section{Findings}

\section{Established Class Norms}

During the time of the observations students were learning about the Pythagorean theorem, finding perimeters of compound figures, working with the geometry of circles, recognizing symmetry of figures, and completing constructions with miras. Students typically discussed more than one topic during the class session due to the nature of the course design. For example, approximately two thirds of the way through the unit under observation, students were applying the knowledge they had gained about the Pythagorean theorem, starting to solidify their understandings of perimeters of compound figures, testing hypothesis about the geometry of circles, and just beginning to explore symmetry.

From the analysis of the observations, it was clear that the flow of class activities throughout the class time was similar and consistent. Students entered the classroom, found their seat in a traditionally arranged college mathematics classroom and talked with each other for approximately the first five minutes of class while the instructor distributed the graded assignments from the previous class meeting. Then she would typically ask, "Okay, let's go ahead and get started. What questions do you have on page ??" At this time students yelled out problem numbers that they did not understand or were not able to complete on that particular page of their assigned homew ork. Next, the instructor asked, "Who would like to come show us how to do this one," and a student volunteer approached the document camera in the front of the room and worked through that particular problem as if she were the teacher providing an example. Once the student finished, the instructor asked if there are any questions for the presenting student and asked the student to answer any questions or reexplain any material as requested by other students. After the problem presentation, the instructor thanked the student, the student returned to his/her seat, and the process was repeated for the next problem on that page. Once all of the questions had been answered for that particular page, the instructor asked if there were are any further questions that needed to be answered over that page and, if not, they moved on to the next page in the assignment. This process was repeated until all of the homew ork problems were presented. Students then stapled all of their homework pages together 
and submitted the as signment to be spot checked for an accuracy grade by a separate grader assigned for the course. While a majority of class time would be used for presentations of problems, rare remaining time would be used to complete an activity designed to explore a conceptual idea about mathematics.

During the presentations of completed problems there was significant amount of shared student thinking. That is, the student typically served as a pseudo-teacher by standing at the front of the class providing a step-by-step explanation of their solution process. Interestingly, it was common for students to believe they must have a correct and final answer before they presented their problem to the class. This was evident through students opting not to present because "they do not have it finished" or by checking their final answer with the instructor prior to presenting the problem. Further, most of the interactions alternated between a single student and the instructor rather than among groups of students as they talked with and built upon on each other's shared thoughts. Although students were doing most of the talking and sharing of their procedural thoughts, they were not working together as a learning community to promote metacognitive development.

\section{Explicit Modeling of Knowledge and Regulation of Cognition}

To better understand the specific types of metacognitive thinking that were shared during the class discussions, Scraw and Dennison's (1994) framework was used to count the frequency of each subcomponent of metacognitive thinking.

Of the 99 total metacognitive episodes, $78 \%$ were episodes of shared Knowledge of Cognition (see Table 1). Declarative statements of knowledge, such as "I am confused if you are supposed to draw the parallel line or the perpendicular line," were made only by the students and consisted of only $4 \%$ of all knowledge of cognition episodes. Procedural knowledge episodes, such as "I started by finding the perimeter of the field...so that would be 200 feet cause this is 550 and 350 so that makes this 200 and..." consist of knowledge about how to implement a procedure and provided $74 \%$ of all shared knowledge episodes. The student-only thoughts provided 54\% of the procedural episodes, $32 \%$ were provided through integrated student-and-teacher thoughts, and $14 \%$ were provided by 
the teacher-only thoughts. Conditional knowledge episodes consist of know ledge about when and why to implement a procedure, such as, "the diagonals of a kite are perpendicular and when bisected, so that is why this one works" and consisted of $22 \%$ of all shared know ledge episodes. There were no student-only thoughts, $76 \%$ were provided through integrated student-and-teacher thoughts, and $24 \%$ were provided through teacher-only thoughts. A summary of this data is provided in Table 1. Sample episodes and descriptors for each category are reported in Appendix A. The data presented here suggests that most of the knowledge of cognition that is shared is procedurally oriented and is provided by the student; however, the sharing of conditional knowledge always involved the teacher.

Table 1

Frequency of Shared Knowledge of Cognition

\begin{tabular}{lcccccccccccc}
\hline Section & \multicolumn{3}{c}{ Declarative } & \multicolumn{3}{c}{ Procedural } & \multicolumn{3}{c}{ Conditional } & \multicolumn{3}{c}{ Totals } \\
\hline & SO* & ST & TO & SO & ST & TO & SO & ST & TO & SO & ST & TO \\
\hline MWF & 2 & - & - & 16 & 10 & 5 & - & 7 & 2 & 18 & 17 & 7 \\
TR & 1 & - & - & 15 & 8 & 3 & - & 6 & 2 & 16 & 14 & 5 \\
Both & 3 & - & - & 31 & 18 & 8 & - & 13 & 4 & 34 & 31 & 12 \\
$\quad$ Grand Totals & & 3 & & & 57 & & & 17 & & & 77 & \\
\hline
\end{tabular}

*SO: student only

ST: integrated student and teacher thoughts

TO: teacher only thought

Regulation of cognition is the second category of metacognitive thought and refers to activities of controlling one's learning. Observation episodes were coded for planning, information management skills, monitoring, debugging, and evaluation. Of the 99 total metacognitive episodes, only $52 \%$ were episodes of shared regulation of cognition in the classroom. See Table 2. Note the fewer instances of regulation of cognition episodes (52\%) in comparison to knowledge of cognition episodes (78\%). Planning episodes consist of planning, goal setting, and allocating resources prior to beginning the task and consisted of only $10 \%$ of the total regulation episodes. Student-only thoughts and integrated student-and-teacher thoughts each provided $20 \%$ of all planning episodes while $60 \%$ were 
provided by teacher-only thoughts. Table 2 presents a summary of the number of episodes relating to sharing of regulation of cognition.

The next three subcomponents of regulation of cognition consist of thoughts occurring during the use of skills and strategies while solving problems. Information management consists of activities such as organizing, elaborating, summarizing or selective focusing that occur during the activity and consisted of $29 \%$ of the regulation of cognition thoughts. Student-only thoughts provided $27 \%$ of the information management skills, 53\% were provided by integrated student-and-teacher thoughts, and $20 \%$ were provided by teacher only regulatory thoughts. Monitoring episodes consists of on-going assessment of one's learning and strategies used while w orking and provided $14 \%$ of all regulation episodes. Student-only thoughts provided $29 \%$ of the monitoring episodes, $57 \%$ were provided by integrated student-and-teacher thoughts, and $14 \%$ were provided by teacher-only thoughts. Debugging is the last subcomponent that occurs during the activity and consists of strategies used to correct understanding and errors. This subcomponent provided $25 \%$ of all regulation episodes. Student-only thoughts provided $7 \%$ of these episodes, $85 \%$ were provided by integrated student-and-teacher thoughts, and $7 \%$ were provided by teacher-only regulatory thoughts.

The final subcomponent of regulation of cognition occurs after the learning experience. Evaluation consists of analyzing performance and effectiveness after the completion of the learning activity and consisted of $22 \%$ of all regulation episodes. There were no student-only or teacher-only evaluation episodes, meaning $100 \%$ of evaluation episodes were provided through integrated student-and-teacher thoughts. There is very little discussion of planning before students began working on a problem and most evaluation occurred through integrated student-and-teacher thinking. Further, most regulatory thoughts occurred during the process of solving the problem and most thoughts were shared through integrated student-andteacher thoughts.

\section{Dual Coding for Both Knowledge and Regulation of Cognition}

Regulation is commonly described as what students are doing with their cognitive knowledge. Hence it makes sense that episodes could be coded for both a knowledge category and a regulation category. 
Table 2

Frequency of Shared Regulation of Cognition

\begin{tabular}{|c|c|c|c|c|c|c|c|c|c|c|c|c|c|c|c|c|c|c|}
\hline & \multicolumn{3}{|c|}{ Planning } & \multicolumn{3}{|c|}{ Info. Mgmt. } & \multicolumn{3}{|c|}{ Monitoring } & \multicolumn{3}{|c|}{ Debugging } & \multicolumn{3}{|c|}{ Evaluation } & \multicolumn{3}{|c|}{ Totals } \\
\hline & $\mathrm{SO}^{*}$ & S & $\mathrm{T}$ & $\mathrm{S}$ & $\mathrm{S}$ & $\mathrm{T}$ & $\mathrm{S}$ & S & $\mathrm{T}$ & $\mathrm{S}$ & $\mathrm{S}$ & $\mathrm{T}$ & S & $\mathrm{S}$ & $\mathrm{T}$ & $\mathrm{S}$ & & \\
\hline & & $\mathrm{T}$ & $\mathrm{O}$ & $\mathrm{O}$ & $\mathrm{T}$ & $\mathrm{O}$ & $\mathrm{O}$ & $\mathrm{T}$ & $\mathrm{O}$ & $\mathrm{O}$ & $\mathrm{T}$ & $\mathrm{O}$ & $\mathrm{O}$ & $\mathrm{T}$ & $\mathrm{O}$ & $\mathrm{O}$ & ST & TO \\
\hline MWF & 1 & 1 & 2 & 1 & 3 & 2 & - & 3 & 1 & - & 6 & 1 & - & 5 & - & 2 & 18 & 6 \\
\hline TR & - & - & 1 & 3 & 5 & 1 & 2 & 1 & - & 1 & 5 & - & - & 6 & - & 6 & 17 & 2 \\
\hline Both & 1 & 1 & 3 & 4 & 8 & 3 & 2 & 4 & 1 & 1 & 11 & 1 & - & 11 & - & 8 & 35 & 8 \\
\hline $\begin{array}{l}\text { Grand } \\
\text { Totals }\end{array}$ & & 5 & & & 15 & & & 7 & & & 13 & & & 11 & & & 51 & \\
\hline
\end{tabular}

SO: student only

ST: integrated student and teacher thoughts

TO: teacher only thought 
For example, a person could be planning how to implement a procedure. In this case the episode would be coded as procedural know ledge and planning regulation. While it is possible for a person to be aware of her know ledge and not do anything with it, it does not seem possible to regulate cognition in the absence of an awareness of some type of knowledge. An analysis of the observation data indicated there was a total of 99 episodes of shared thinking, see Table 3. Of those 99, 33 episodes were coded with both a knowledge and a regulation subcomponent leaving 44 statements coded as only knowledge and 18 coded as only regulatory. At first glance, it seems odd to have 18 statements coded as regulation without any knowledge; however, it is possible that the knowledge statement was not made explicit during the episode. Table 3 displays a summary of the statements that received both a knowledge and regulation code.

From the observation data, it can be concluded that the sharing of metacognitive knowledge is more frequent than the sharing of regulatory knowledge. Further, procedural knowledge far exceeds any other type of metacognitive thought shared in this classroom and is commonly done either by the students themselves or in conjunction with the teacher. There are very few episodes which represent declarative thinking. Regulatory thinking is typically shared through episodes that consisted of integrated thinking by the student and by the instructor.

Table 3

Episodes Codedfor both KnowledgeandRegulation of Cognition

Knowledge of Cognition

\begin{tabular}{|c|c|c|c|c|c|}
\hline & & Declarative & Procedural & Conditional & Total \\
\hline \multirow{6}{*}{ 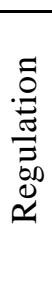 } & Planning & - & $1^{*}$ & 1 & 2 \\
\hline & Info Mng & 1 & 10 & - & 11 \\
\hline & Monitoring & - & 4 & - & 4 \\
\hline & Debugging & - & 5 & 2 & 7 \\
\hline & Evaluation & - & 1 & 8 & 9 \\
\hline & Total & 1 & 21 & 11 & 33 \\
\hline
\end{tabular}

*Number of Occurrences 


\section{Teachers Role in Promoting Metacognition}

The findings from the observations show an emphasis on how students modeled their procedural understandings of the w ork they were doing. The important role of the instructor in helping he students become more aw are of their thinking is evident in the high frequency of integrated student-andteacher thoughts. Near the end of the semester, the students were unable to share their thoughts without the support of the teacher. Using prompting and questioning to help students describe their thinking assists in the development of a community where students feel comfortable and thus their own thoughts become critical elements in the development of metacognitive thinking. Three main ideas (the use of strategies, the development of dialogue, and creating social supports) are described in the literature as ways to promote the sharing of thinking and thus promote metacognitive development. Information from the observations was explored for each of these ideas as a way to paint a picture of how the instructor used metacognitive strategies, the development of effective dialogue, and the creation of social supports to promote metacognitive thinking in her students.

\section{Strategies Identified in the Observations}

Creating a learning environment that promotes metacognitive development hinges on the sharing of thinking and common strategies to help students become more aware of their own thinking. These activities include modeling, prompting, questioning, analyzing errors, and reflecting on experiences. From the observation data, there are 99 episodes of shared thinking, indicating thinking is being made visible and, more importantly, although at differing frequencies, both the students and the teacher are modeling their thinking. While the students frequently modeled their own procedural knowledge, the instructor tended to integrate her thinking with those of the students rather than modeling her own thought processes as an example.

A second strategy used frequently to help students share their thinking was the use of prompts and questions such as, "What do you need to do next?" or "How do you do that?" The use of prompts and questions was evident through the integrated student-and-teacher thoughts representing 
$40 \%$ of the total knowledge of cognition episodes and $69 \%$ of the total regulation of cognition episodes. These results suggest the students tend to have an initial thought, but are not able to work through the entire idea completely on their own and thus need to be prompted or questioned through the development of the remaining thought.

A third strategy common in the literature is analyzing errors. This activity can be present in either debugging while solving or through the evaluation after solving the problem. In either case nearly all of the episodes of debugging and evaluation, 85\% debugging and $100 \%$ evaluation, were integrated student-and-teacher thinking, with only a single episode being completed by a student. Although procedural thinking is being modeled, students are not sharing their own thoughts related to their regulation of cognition.

The sharing of procedural knowledge by the students was prevalent in these two sections; however, conditional knowledge required prompting by the instructor. A similar statement can also be made about regulation in general. Most regulatory thoughts required the assistance of the instructor, very few were made by only the student. Regarding the type of cognition that was modeled, knowledge of cognition episodes were much more prevalent than regulation of cognition episodes.

\section{Discussion}

The findings of this study suggest that there is only a limited amount of explicit metacognitive thinking shared in this geometry content course designed specifically to promote inquiry-based and student-centered instruction. This particular course is considered to be a strong example of a non-traditional approach to instruction, thus students are leaving this course having not experienced classroom instruction that promotes metacognitive development. While this is problematic, it is also important to consider just how close the instructor did get to the idealistic setting and look at how she could have made very minor changes to instruction that would have taken the discussion into a sharing of metacognition.

The instructor in this course provided opportunities for students to share their thinking with the class and prompted students, as needed, as they worked through problems they were presenting. Further, the instructor encouraged students to ask each other questions and to evaluate methods 
that were presented to the class. Interestingly, even though she did include think aloud, modeling, prompting, and questioning as a major focus for instruction (all strategies for promoting metacognitive development), the instructor did not facilitate these activities in a way that promoted the development of metacognition beyond students' procedural knowledge.

Reflection is perhaps one of the most talked about strategies in the literature, aside from think aloud, to develop students' metacognitive thinking (Cardelle-Elawar, 1995; Cohors-Fresenborg, et al., 2010). The process of reflection can be completed through writing, group discussions, or through interpersonal communications. Within the framework used for the classroom observations, reflection falls under evaluation (Schraw \& Dennison, 1994). A reflective activity requires a student to look back and consider the effectiveness and efficiency of a particular process rather than simply recalling the process (Yimer \& Ellerton, 2010).

Reflection was perhaps one of the least used strategies in the observed course. In asking the students if they understood or if they had questions for the student that had just presented a problem, the instructor did not prompt the students to reflect on their own work. There were no explicit episodes of reflection observed, and reflection was not discussed during the instructor interviews or on the student surveys, though perhaps the instructor perceived reflection to be a natural automatized process and thus overlooked ways to help students develop their ability to reflect on their ow n w ork. In addition, there were no direct instructions within the textbook problems that required the students to reflect on their work. Because of the importance of reflection in the overall process of developing metacognitive thinking (Cardelle-Elawar, 1995; Yimer \& Ellerton, 2010), it is important to develop a better understanding of why reflection was overlooked and how to support the instructor's awareness of the need to teach students how to reflect and to learn from those reflections.

The lack of reflection in the class was not the only way the instructor missed an opportunity for promoting metacognitive development. There were several instances during the observations where the discussion lead up to a point where the instructor had a choice about which direction to steer the conversation and she chose, consciously or subconsciously, to steer aw ay from discussion that would promote metacognitive development. The instructor likely did not realize this was occurring; however, reflecting on and identifying where the conversation could have moved in a different 
direction is important for future growth. For example, when selecting a single representative problem from a page, the instructor often made a suggestion to a student based on the perceived difficulty level of the problem, but did not facilitate a discussion as to why that problem seemed more difficult or how students could create a plan for solving the problem.

As another example, when an incorrect solution was presented, the instructor was very concerned about students' feelings. She made sure they were not embarrassed and tried to limit confusion among other students by working quickly to identify the error and have another student provide a correct explanation. Rather than quickly glossing over the incorrect explanation, the instructor could have questioned and prompted students through the debugging process (Schoenfeld, 1992). This instructor also could have had other students provide possible strategies then promoted and facilitated a discussion using regulation of cognition to compare and evaluated the multiple strategies that were presented, without first identifying the accuracy of possible methods proposed by students (Kramarski \& Zoldan, 2008).

During the observations, when a student identified a need for help on a problem, the instructor asked for a volunteer who came to the front of the room and explained how he/she worked the problem. Further, when a student didn't understand something in the explanation, the instructor would have the student who was presenting repeat that part of their explanation. Rather than jump straight into a procedural explanation of the problem, students could have been asked questions about what they did or did not know and how to develop a plan for getting to the solution. This process w ould have modeled regulation of cognition by helping the student identify what they did and did not understand so that they could enter the regulatory process (Cardelle-Elawar, 1995). There were several examples where the students' questions about a problem did not require the full procedural explanation, but instead a quick prompt to help them sort through information they already knew.

A final example of missed opportunities occurred when the instructor chose not to discuss and present multiple strategies for solving a problem. When multiple strategies were presented, the students were left to choose whichever method they liked best without any discussion. Having an explicit discussion, about when a particular procedure would be better than another procedure, is important in developing conditional knowledge, one 
type of metacognitive thinking. This type of discussion also provides insight into regulatory processes as well. While this list is in no way intended to be exhaustive, it does show a variety of examples of times when the instructor lead right up to, but failed to open the door for explicit metacognitive development. A better understanding of why these choices were made is important for promoting metacognitive development in the future.

This naturalistic qualitative study provides an outsiders perspective to what is occurring in only a single mathematic s content classroom for preservice elementary teachers. This study did not capture the thinking and beliefs of either the students or the course instructor. These thoughts and beliefs are important in understanding the overall picture of the learning environment and could be explored through methods such as surveys or stimulated video recall interviews. Further, this study was conducted at a point in the semester after class norms had already been established. It is possible that the thinking shared earlier in the semester may have been different and students had already internalized the process of thinking metacognitively. While this internalization process may be an ultimate goal, the lack of thought sharing may be problematic for future teachers that should work to develop multiple pathways to understanding content thus helping them manage future discussions in their own classrooms. Conducting classroom observations throughout the semester would provide a better understanding of the overall development of metacognitive thinking as a part of this course. Likewise, following opportunities for learning about and developing metacognitive thinking across the entire teacher education program could also be valuable in learning about and understanding teacher change and implementation of the Eight Mathematical Practices.

Unfortunately, in many mathematics classrooms mathematic s instruction is limited to developing procedural know ledge and tends to overlook all of the other elements of metacognition such as the underlying thinking processes and reasons for making particular decisions for completing problems. It is through the sharing, comparing, and internalizing of thought processes that a student is able to develop a new schema for selecting and applying a particular strategy in a new context. The teaching of mathematics needs to move aw ay from the rote memorization mathematical procedures with no meaning to instead focus on developing thinking and reasoning skills in all students. Continued exploration of the relationship 
between metacognitive thinking, developing metacognition, and good standards-based instruction will continue to provide understanding about how to break the teaching like they were taught cycle present in many mathematics classrooms. Teachers must learn how to create and manage environments full of rich and diverse thinking that requires students to analyze, critique, and reflect on thinking that has been shared thus developing critical thinkers for the future.

\section{References}

Aichele, D., \& Wolfe, J. (2008). Geometric Structures: An Inquiry-Based Approach for Prospective Elementary and Middle School Teachers. Upper Saddle River: Pearson Education, Inc.

Bransford, J. D., Brown, A.L., \& Cocking, R.R. (2000). How People Leam: Brain, Mind, Experience, and School. Washington, D.C.: National Academies Press.

Cardelle-Elaw ar, M. (1995). Effects of metacognitive instruction on low achievers in mathematics problems. Teaching and Teacher Education, 11(1), 81-95. doi:10.1016/0742-051X(94)00019-3 Cohors-Fresenborg, E., Kramer, S., Pundsack, F., Sjuts, J., \& Sommer, N.

(2010). The role of metacognitive monitoring in explaining differenced in mathematics achievement. ZDM Mathematics Education, 42, 231-244. doi: 10.1007/s11858-010-0237-X

Craw ford, G. B. (2007). Brain-Based Teaching with Adolescent Learning in Mind (Second ed.). Thousand Oaks, CA: Sage Publications.

Emerson, R. M., Fretz, R. I., \& Shaw, L. L. (1995). Writing Ethnographic

Fieldnotes. Chicago: University of Chicago Press.

Flavell, J. H. (1979). Metacognition and cognitive monitoring: A new area of cognitive-developmental inquiry. American Psychologist, 34(10), 906-911. doi: 10.1037/0003-066X.34.10.906

Garofalo, J., \& Lester, F. K. (1985). Metacognition, cognitive monitoring, and mathematic al performance. Journal for Research in Mathematics Education, 16(3), 163-176. doi: 10.2307/748391

Goos, M., Galbraith, P., \& Renshaw, P. (2002). Socially mediated metacognition: Creating collaborative zones of proximal development in small group problem solving. Educational Studies in Mathematics, 49(2), 193-223. doi: 10.1023/A:1016209010120 
Kramarski, B., \& Zoldan, S. (2008). Using errors as springboards for enhancing mathematical reasoning with three metacognitive approaches. Journal of Educational Research, 102(2), 137-151. doi: 10.3200/JOER.102.2.137-151

Lester, F. K. (1989). Reflections about mathematical problem-solving research. The teaching and assessing of mathematical problem solving, 3, 115-124.

Lin, X. (2001). Designing metacognitive activities. Educational Technology Research and Development, 49(2), 23-40. doi: 10.1007/BF02504926 Martinez, M. E. (2006). What is metacognition? Phi Delta Kappan, 87(9), 696-699.

Merriam, S. (1998). Qualitative Research and Case Study Applications in Education. San Francisco: Jossey Bass.

National Council of Teachers of Mathematics, N. (2000). Principles and Standards for School Mathematics. Reston, VA: NCTM.

National Research Council. (2001). Adding it up: Helping children learn mathematics. J. Kilpatrick, J. Sw afford, and B. Findell (Eds.). Washington, DC: National Academy Press.

Patton, M. (2002). Qualitative Research and Evaluation Methods (3rd ed.). Thousand Oaks: Sage Public ations.

Pintrich, P. R. (2002). The role of metacognitive know ledge in learning, teaching, and assessment. Theory into Practice, 41(4), 219-225.

Pugalee, D. K. (2001). Writing, mathematics, and metacognition: Looking for connections through students' work in mathematical problem solving. School Science and Mathematics, 101(5), 236-245. doi: 10.1207/s15430421tip4104_3

Sarver, M. E. (2006). Metacognition and Mathematical Problem Solving: Case Studies of Six Seventh Grade Students (Doctoral dissertation, Montclair State University).

Schoenfeld, A. (1992). Learning to think mathematically: Problem solving, metacognition, and sense-making in mathematics. In D. Grouws (Ed.), Handbook for Research on Mathematics Teaching and Learning (pp. 334-370). New York: MacMillan.

Schoenfeld, A. (2007). What is mathematical proficiency and how can it be assessed? In A. Schoenfeld (Ed.), Assessing Mathematical Proficiency (Vol. 53, pp. 59-73). Cambridge: Cambridge University Press. 
Schraw, G., \& Dennison, R. S. (1994). Assessing metacognitive aw areness. Contemporary Educational Psychology, 19(4), 460-475. doi:

10.1006/ceps.1994.1033

Vygostsky, L.S. (2012). Thought and language. MIT Press: Cambridge, MA.

Yimer, A., \& Ellerton, N. F. (2010). A five-phase model for mathematical problem solving: Identifying synergies in pre-service teachers' metacognitive and cognitive actions. ZDM Mathematics Education, 42, 245-261. doi: 10.1007/s11858-009-0223-3

Kansas Conrady is an Assistant Professor in department Instructional Leadership and Academic Curriculum, in the University of Oklahoma, United States of America.

Contact Address: Direct correspondence concerning this article, should be addressed to the author. Postal address: 820 Van Vleet Oval \#114; Norman, OK; 73019 (United States of America). Email:

Kansas.conrady@ou.edu 
Table 4

\section{Appendix A}

Descriptors and examples of subcomponent coding

\begin{tabular}{|c|c|c|}
\hline $\begin{array}{l}\text { Subcomponent of } \\
\text { Metacognition }\end{array}$ & $\begin{array}{l}\text { MAI Questions Related to } \\
\text { Subcomponent (question \#) }\end{array}$ & Sample Episode for Subcomponent \\
\hline $\begin{array}{l}\text { Declarative } \\
\text { Knowledge } \\
\text { knowledge about } \\
\text { one's skills, } \\
\text { intellectual resources, } \\
\text { and abilities as a } \\
\text { learner }\end{array}$ & $\begin{array}{l}\text { Knowledge } \\
\text { I understand my intellectual } \\
\text { strengths and weaknesses (5) } \\
\text { I know what kind of } \\
\text { information is most important } \\
\text { to learn (10) } \\
\text { I am good at organizing } \\
\text { information (12) } \\
\text { I know what the teacher } \\
\text { expects me to learn (16) } \\
\text { I am good at remembering } \\
\text { information (17) } \\
\text { I have control over how well I } \\
\text { learn } 20 \text { ) } \\
\text { I am a good judge of how well } \\
\text { I understand something (32) } \\
\text { I learn more when I am } \\
\text { interested in the topic (46) }\end{array}$ & $\begin{array}{l}\text { Cognition } \\
\text { Student: I am confused on if you are supposed to draw } \\
\text { the parallel line or the perpendicular line }\end{array}$ \\
\hline
\end{tabular}




\section{Conrady-Modeling Metacognition}

Table 4

Descriptors and examples of subcomponent coding (.../...)

\begin{tabular}{|c|c|c|}
\hline $\begin{array}{l}\text { Subcomponent of } \\
\text { Metacognition }\end{array}$ & $\begin{array}{l}\text { MAI Questions Related to } \\
\text { Subcomponent (question \#) }\end{array}$ & Sample Episode for Subcomponent \\
\hline $\begin{array}{l}\text { Procedural } \\
\text { Knowledge } \\
\text { knowledge about how } \\
\text { to implement learning } \\
\text { procedures (eg } \\
\text { strategies) }\end{array}$ & $\begin{array}{l}\text { I try to use strategies that have } \\
\text { worked in the past ( } 3 \text { ) } \\
\text { I have a specific purpose for } \\
\text { each strategy I use (14) } \\
\text { I am aware of what strategies I } \\
\text { use when I study (27) } \\
\text { I find myself using helping } \\
\text { learning strategies } \\
\text { automatically (33) }\end{array}$ & $\begin{array}{l}\text { Instructor: number eight... we are waiting patiently } \\
\text { for somebody to get up the courage to come attack this } \\
\text { problem } \\
\text { Student: alright, how long would it take Joanna to } \\
\text { walk around the trapezoidal field pictured here if she } \\
\text { walks at a rate of } 300 \text { feet per minute, I started by } \\
\text { finding the perimeter of the field, what would you call } \\
\text { that?, altitude? } \\
\text { Instructor: (shakes her head yes) absolutely, which we } \\
\text { will talk about next } \\
\text { Student: so that would be } 200 \text { feet cause this is } 550 \\
\text { and } 350 \text { so that makes this } 200 \text { and because this is } 200 \\
\text { this one would also be } 200 \text { so I am gonna find the } \\
\text { hypotenuse of that triangle } 200 \text { squared plus } 200 \\
\text { squared equals c squared, } 200 \text { squared is forty } \\
\text { thousand plus forty thousand, will you stop me if I am } \\
\text { doing this wrong? } \\
\text { Instructor: you are doing fine, I'm sure they'll let you } \\
\text { know (pointing to the class) }\end{array}$ \\
\hline
\end{tabular}


Table 4

Descriptors and examples of subcomponent coding (.../...)

\begin{tabular}{|c|c|c|}
\hline $\begin{array}{l}\text { Subcomponent of } \\
\text { Metacognition }\end{array}$ & $\begin{array}{l}\text { MAI Questions Related to } \\
\text { Subcomponent (question \#) }\end{array}$ & Sample Episode for Subcomponent \\
\hline $\begin{array}{l}\text { Conditional } \\
\text { Knowledge } \\
\text { knowledge about } \\
\text { when and why to use } \\
\text { learning procedures }\end{array}$ & $\begin{array}{l}\text { I learn best when I know } \\
\text { something about the topic (15) } \\
\text { I use different learning } \\
\text { strategies depending on the } \\
\text { situation (18) } \\
\text { I can motivate myself to learn } \\
\text { when I need to (26) } \\
\text { I use my intellectual strengths } \\
\text { to compensate for my } \\
\text { weaknesses (29) } \\
\text { I know when each strategy I } \\
\text { use will be most effective (35) }\end{array}$ & $\begin{array}{l}\text { Instructor: this way if you connect the dots, you find } \\
\text { what type of quadrilateral? } \\
\text { Student: kite } \\
\text { Instructor: yeah, a kite and the diagonals of a kite are } \\
\text { perpendicular and when bisected, so that is why this } \\
\text { one works, but if you have something that works, } \\
\text { there are other ways, yes [there is another way to do } \\
\text { this construction of reflecting a point over a line with } \\
\text { a compass and straightedge] }\end{array}$ \\
\hline Planning & $\begin{array}{l}\text { I pace myself while learning in } \\
\text { order to have enough time (4) }\end{array}$ & $\begin{array}{l}\text { Student: so I guess we just use Pythagorean Theorem } \\
\text { on all of these? We are trying to find which ones are }\end{array}$ \\
\hline $\begin{array}{l}\text { planning, goal setting, } \\
\text { and allocating } \\
\text { resources prior to } \\
\text { learning }\end{array}$ & $\begin{array}{l}\text { I think about what I really need } \\
\text { to learn before I begin a task } \\
\text { (6) } \\
\text { I set specific goals before I } \\
\text { begin a task ( } 8 \text { ) }\end{array}$ & $\begin{array}{l}\text { the point, the distance right? Okay (student draws in } \\
\text { right triangle and finds length) }\end{array}$ \\
\hline
\end{tabular}




\section{Conrady - Modeling Metacognition}

Table 4

Descriptors and examples of subcomponent coding (.../...)

\begin{tabular}{ll}
\hline $\begin{array}{l}\text { Subcomponent of } \\
\text { Metacognition }\end{array}$ & $\begin{array}{l}\text { MAI Questions Related to } \\
\text { Subcomponent (question \#) }\end{array}$ \\
\hline & I ask myself questions about \\
& the material before I begin (22) \\
& I think of several ways to solve \\
& a problem and choose the best \\
& one (23) \\
& I read instructions carefully \\
before I begin a task (42) & I organize my time to best \\
& accomplish my goals (45) \\
I slow down when I encounter \\
information & important information (9) \\
Management Skills & I consciously focus my \\
& attention on important \\
skills and strategy & information (13) \\
sequences used on- & I focus on the meaning and \\
line to process & significance of new \\
information more & information (30) \\
efficiently (eg & I create my own examples to \\
organizing, & make information more \\
elaborating, & meaningful (31) \\
summarizing, &
\end{tabular}


Table 4

Descriptors and examples of subcomponent coding (.../...)

\begin{tabular}{|c|c|c|}
\hline $\begin{array}{l}\text { Subcomponent of } \\
\text { Metacognition }\end{array}$ & $\begin{array}{l}\text { MAI Questions Related to } \\
\text { Subcomponent (question \#) }\end{array}$ & Sample Episode for Subcomponent \\
\hline selective focusing) & $\begin{array}{l}\text { I draw pictures or diagrams to } \\
\text { help me understand while } \\
\text { learning (37) } \\
\text { I try to translate new } \\
\text { information into my own words } \\
\text { (39) } \\
\text { I use the organizational } \\
\text { structure of the text to help me } \\
\text { learn ( } 41 \text { ) } \\
\text { I ask myself if what I'm reading } \\
\text { is related to what I already } \\
\text { know (43) } \\
\text { I try to break studying down } \\
\text { into smaller steps ( } 47 \text { ) } \\
\text { I focus on overall meaning } \\
\text { rather than specifics (48) }\end{array}$ & $\begin{array}{l}\text { Instructor: let's summarize a and b, what are you } \\
\text { trying to find for a? the circumcenter of the } \\
\text { circumscribing circle, in order to find the } \\
\text { circumcenter... that's the point where what meets? } \\
\text { Student: all the bisectors come together } \\
\text { Instructor: be more specific for me, all the bisectors.... } \\
\text { Student: perpendicular? } \\
\text { Instructor: perpendicular bisectors, so in other words } \\
\text { you need all three perpendicular bisectors, how do you } \\
\text { find perpendicular bisectors? } \\
\text { Student: you fold the paper and touch the points } \\
\text { describing paper folding } \\
\text { Instructor: so you do what you did back on number } \\
\text { one, you have an example of perpendicular bisectors } \\
\text { from number } 1 \text {, you just did it, so do what you did on } \\
\text { number one three times...b, what are you trying to } \\
\text { find on b? }\end{array}$ \\
\hline Monitoring & $\begin{array}{l}\text { I ask myself periodically if I } \\
\text { am meeting my goals (1) }\end{array}$ & $\begin{array}{l}\text { Student: instead of uhm, her choosing two different } \\
\text { points, can I just choose the one point and draw the }\end{array}$ \\
\hline assessments of one's & I consider several alternatives & from point $\mathrm{p}$ through the line and then use it \\
\hline
\end{tabular}


158 Conrady-Modeling Metacognition

Table 4

Descriptors and examples of subcomponent coding (.../...)

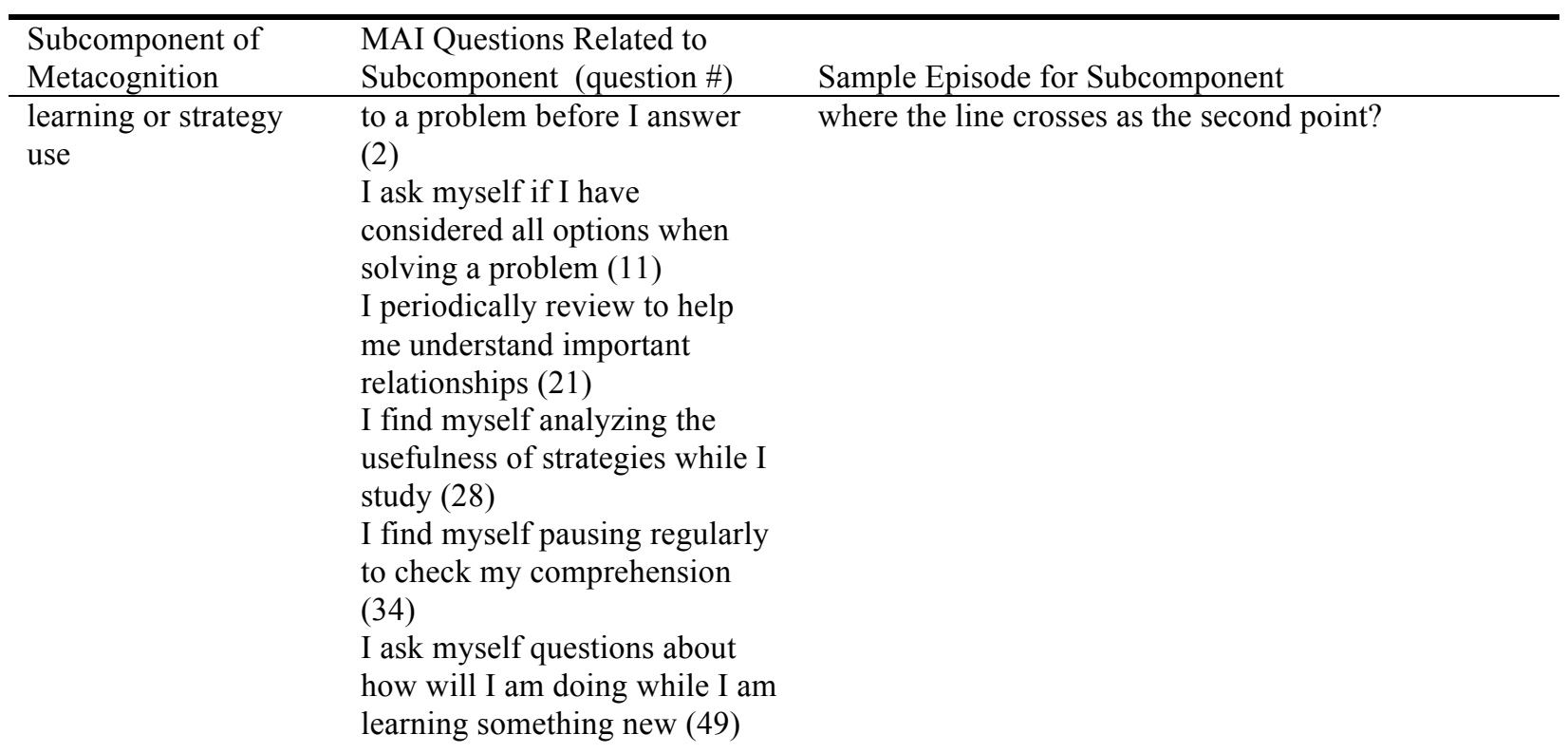


Table 4

Descriptors and examples of subcomponent coding (.../...)

\begin{tabular}{|c|c|c|}
\hline $\begin{array}{l}\text { Subcomponent of } \\
\text { Metacognition }\end{array}$ & $\begin{array}{l}\text { MAI Questions Related to } \\
\text { Subcomponent (question \#) }\end{array}$ & Sample Episode for Subcomponent \\
\hline $\begin{array}{l}\text { Debugging } \\
\text { strategies used to } \\
\text { correct } \\
\text { comprehension and } \\
\text { performance errors }\end{array}$ & $\begin{array}{l}\text { I ask others for help when I } \\
\text { don't understand something } \\
(25) \\
\text { I change strategies when I fail } \\
\text { to understand (40) } \\
\text { I reevaluate my assumptions } \\
\text { when I get confused (44) } \\
\text { I stop and go back over new } \\
\text { information that is not clear } \\
\text { (51) } \\
\text { I stop and reread when I get } \\
\text { confused (52) }\end{array}$ & $\begin{array}{l}\text { Student: are we supposed to know to extend the lines } \\
\text { Instructor: yeah lets talk about that, it's a good } \\
\text { question there, how did <student }>\text { know to extend the } \\
\text { lines? } \\
\text { Student: the directions say to } \\
\text { Student: obtuse angle } \\
\text { Instructor: say that again } \\
\text { Student: any time the triangle is obtuse, the line } \\
\text { Instructor: how do you know which lines to extend? } \\
\text { Student: uh the ones of the leg, uh the shortest sides } \\
\text { you extend } \\
\text { Student: if you had it as the floor and dropped a strong } \\
\text { from the vertex } \\
\text { Instructor: any body view it differently? Okay are we } \\
\text { done with this page? }\end{array}$ \\
\hline $\begin{array}{l}\text { Evaluation } \\
\text { analysis of } \\
\text { performance and } \\
\text { strategy effectiveness } \\
\text { after a learning }\end{array}$ & $\begin{array}{l}\text { I know how well I did once I } \\
\text { finish a test ( } 7 \text { ) } \\
\text { I ask myself if there was an } \\
\text { easier way to do things after I } \\
\text { finish a task (19) } \\
\text { I summarize what I've learned }\end{array}$ & $\begin{array}{l}\text { Instructor: will it work? (students wait and look to her } \\
\text { for answer) you tell me? Did it? (students discussing } \\
\text { amongst their neighbors) how did you check? How } \\
\text { did you check to see if you construction worked? } \\
\text { Student: mira? } \\
\text { Instructor: yeah, whip out your mira, just like number }\end{array}$ \\
\hline
\end{tabular}


160 Conrady-Modeling Metacognition

Table 4

Descriptors and examples of subcomponent coding (.../...)

\begin{tabular}{lll}
\hline $\begin{array}{l}\text { Subcomponent of } \\
\text { Metacognition }\end{array}$ & MAI Questions Related to & \\
\hline episode & Subcomponent (question \#) & Sample Episode for Subcomponent \\
\hline & I aster I finish (24) & 1 and check it \\
& accomplished my goll I & \\
& I'm finished (36) \\
& I ask myself if I have & \\
& considered all options after I \\
& solve a problem (38) \\
& I ask myself if I learned as \\
& much as I could have once I \\
& finish a task (50) \\
\hline
\end{tabular}

